\title{
CHARACTERIZATION OF TEA (CAMELLIA SINENSIS L.) GENOTYPES GROWN IN TURKEY BY ISSR MARKERS
}

\author{
YOGURTCU, B. ${ }^{1}-$ AYGUN, A..$^{*}$ \\ ${ }^{1}$ Department of Horticulture, Faculty of Science, Ordu University, 52000 Ordu, Turkey \\ ${ }^{2}$ Department of Biology, Faculty of Arts and Science, Kocaeli University, 41380 \\ Kocaeli, Turkey \\ (current address: Department of Horticulture and Field Crops, Faculty of Agriculture, \\ Kyrgyz Turkish Manas University, 720044 Bishkek, Kyrgyzstan) \\ *Corresponding author \\ e-mail: ahmet.aygun@kocaeli.edu.tr
}

(Received 25 ${ }^{\text {th }}$ May 2021; accepted $3^{\text {rd }}$ Sep 2021)

\begin{abstract}
The aim of this study was to determine the genetic diversity of 18 tea (Camellia sinensis) genotypes and 6 varieties collected from different provinces in the Black Sea region of Turkey. DNA isolation was performed according to the CTAB method of tea samples. PCR was performed for all DNA samples with 59 ISSR primers. In order to determine the genetic relationship between tea genotypes among these primers, 15 polymorphic ISSR primers were used. At the end of the PCR procedures, the polymorphism rate was determined as $77 \%$ from the bands formed. As a result of the analysis of products obtained by PCR studies, 109 bands were obtained in ISSR primers. The obtained bands were scored as presence (1) and absence (0) and their files were created. A genetic relation dendrogram was formed according to the obtained band results. Genetic diversity of tea genotypes and varieties of the Black Sea region was determined by molecular markers.
\end{abstract}

Keywords: Camellia sinensis, CTAB, endangered, Taq polymorphism, PCR

\section{Introduction}

Turkey has a rich flora due to its geographical location, soil structure, and climate diversity. These characteristics allow Turkey to be one of the leading countries in the world in terms of plant diversity since it has many plant species growing naturally or is the gene center for many of them (Briggs and Knowles, 1967; Harlan, 1995; Kaya and Raynal, 2001; Ercisli, 2004; Altindal, 2019). Turkey has a diverse ecology allowing cultivation of a lot of horticultural crops of temperate, subtropical and semi tropical climates, in a narrow area in the south. Tea (Camellia sinensis L.) is a plant owes which its leaves and buds are used to produce beverages. The species belongs to the Theaceae family that grows in humid climates (Benzie and Szeto, 1999; Ferruzzi, 2010; Panda, 2011). Although it originates from is South and Southeast Asia, it is also grown in tropical and subtropical regions around the world (De Costa et al., 2007). The plants are small trees less than $2 \mathrm{~m}$ and are evergreen Tea is produced in 45 countries in an area of approximately 5 million 561 thousand hectares in the world. China is the leading country $(36 \%)$ in world's dry tea production and Turkey ranks fifth $(4 \%)$ (Anonymous 2016; Anonymous, 2018). Tea is cultivated in an area of provinces encompasses the Rize $(65 \%)$, Trabzon (21\%), Artvin (11\%), Giresun (2\%), and Ordu (1\%) in 82.951 ha land in the Eastern Black Sea region, Turkey. Approximately, 22.331.000 tons of fresh tea leaves are harvested by 212.692 growers, and later transformed into 230,000 tons of dried leaves for brewing every year (Anonymous, 2018). 
The first tea cultivation in Turkey started in 1937 with the importation of 20 tons of tea seeds from Georgia. With these seeds, the first tea orchards were established in Rize and Artvin provinces. Over the years, new orchards and gardens in other provinces have continued to be established with the seeds obtained from these gardens. New varieties have been obtained by selecting individuals with superior characteristics, which differ in terms of morphological features, from these gardens, which were formed from seeds over time. Tea plants are mostly propagated by seeds in Turkey, although there are several clones, which creates wide genetic diversity resulting in variation in yield and quality. While this variation is not desirable for a standardized cultivation and highquality leaf, it could provide new opportunities in development of new cultivars with superior characteristics from the established population by phenotypic selection. Therefore, it is important to determine the tea genetic sources. These differences also led to the emergence of close and distant inbreeding in the plant. Genetic differences were evaluated by researchers (Kafkas et al., 2009). In general, morphological characteristics are used in identifying superior genotypes, however, they are affected by cultivation techniques and ecological factors. Besides, selection breeding takes long time many years. Molecular marker technology has enabled the adoption of wideranging new applications to improve selection strategies in plant breeding (Upadhyaya et al., 2008; Bandyopadhyay, 2011; Abdel-Mawgood, 2012; Rajpal et al., 2016; Rahimi et al., 2018). Information obtained in recent years on plant molecular marker genetics can be reflected in plant breeding studies. For this reason, newly developed or modified plant breeding methods should be used based on information obtained from plant molecular biology studies. With the use of molecular markers in plant breeding, the efficiency of classical breeding is improved by providing advantages such as backcross breeding, creation of gene pyramids, selection of recessive genes, gene transfer from wild genetic resources, and early selection, thus accelerating the development of new varieties (Nybom et al., 2014). Although molecular marker applications alone cannot be used as a substitute for classical breeding, they are considered as a complementary technique that increases the success of classical breeding. In tea, several molecular markers have been used (Roy et al., 2009; Zang et al., 2018). Different markers have different advantages such as SSR and AFLP markers for polymorphism, RAPD and ISSR markers for cost efficiency, RFLP, SSR, SRAP, ISSR, and AFLP markers for repeatability. One of the widely used markers is ISSR markers (Lai et al., 2001; Yao et al., 2008; Ji et al., 2011; Rahimi et al., 2019).

Tea is grown naturally in the provinces of Rize, Artvin, Trabzon, Giresun, and Ordu in the eastern Black Sea region of Turkey. Of the total of 829.505 decares planted tea areas in these regions, 65\% was in Rize, 21\% in Trabzon, 11\% in Artvin, 2\% in Giresun, and 1\% in Ordu. Every year, around 212.692 farmers harvest around 22.331 million tons of fresh tea leaves in the region. Approximately 220,000-230,000 tons of dry teas are produced from this amount of fresh leaves (Anonymous, 2018). Seeds are used as plant material in the creation of tea fields in our country. A large proportion of genetic variation occurs in gardens created from seeds. Therefore, it is important to determine the tea genetic sources in our country. In this study, by using the ISSR markers, it was aimed to make distinctions of tea genotypes and registered tea varieties selected as representatives of tea fields grown in Turkey.

The aim of the study was to molecular characterization of tea genotypes with seedling origin and registered tea clones grown in the Eastern Black Sea Region of Turkey by using the ISSR markers. 


\section{Materials and methods}

\section{Plant material}

A total of 24 Camellia sinensis L. genotypes representing all of the intensive tea growing provinces in the Eastern Black Sea region were used in the study. The genotypes were consisted of 18 seedlings selected from provinces ( 8 from Rize, 5 from Giresun, 2 from Artvin, 2 from Trabzon, and 1 from Ordu), and 6 clonally propagated standard varieties maintained in collection plots of Çaykur Atatürk Tea and Horticultural Research Institute in Rize (Table 1; Fig. 1). Leaf samples were collected from freshly growing shoots

\section{DNA isolation}

Genomic DNA isolation was performed by cetyltrimethylammonium bromide (CTAB) method (Saghai-Maroof et al., 1984) in the Genome and Stem Cell Research Laboratory at Erciyes University, Kayseri. DNA concentrations were determined and the purity (A260/A280) was checked by using BioSpec-nano Shimadzu Biotech spectrophotometer that DNA sufficient quality was used in ISSR-PCR studies. DNA concentration was diluted to $20 \mathrm{ng} / \mu \mathrm{l}$, and the DNA was maintained at $-20{ }^{\circ} \mathrm{C}$ until use.

Table 1. Places where they are taken and codes of tea genotypes and varieties used in the study

\begin{tabular}{c|c|c}
\hline No & Province of origin & Country \\
\hline 1 & Pazar1 & RIZE \\
2 & Pazar2 & RİZE \\
3 & Hopa & ARTVIN \\
4 & Arhavi & ARTVIN \\
5 & Findıkl & RİZE \\
6 & Ardeşen & RİZE \\
7 & Hayrat1 & TRABZON \\
8 & Of & TRABZON \\
9 & İidere & RİZE \\
10 & Derepazar1 & RİZE \\
11 & Güneysu & RİZE \\
12 & Çayeli & RIZZE \\
13 & Fener3 & RİZE and AÇBKAE \\
14 & Fener & RİZE and AÇBKAE \\
15 & Hayrat2 & RİZE and AÇBKAE \\
16 & Hamzabey & RİZE and AÇBKAE \\
17 & Muradiye10 & RİZE and AÇBKAE \\
18 & Enstitü & RİZE and AÇBKAE \\
19 & Tirebolu1 & GİRESUN \\
20 & Tirebolu2 & GİRESUN \\
21 & Tirebolu3 & GİRESUN \\
22 & Tirebolu4 & GİRESUN \\
23 & Tirebolu5 & GİRESUN \\
24 & Perşembe & ORDU \\
\hline AĊBKAE:A & \\
\hline
\end{tabular}

AÇBKAE: Atatürk Tea and Horticultural Research Institute 


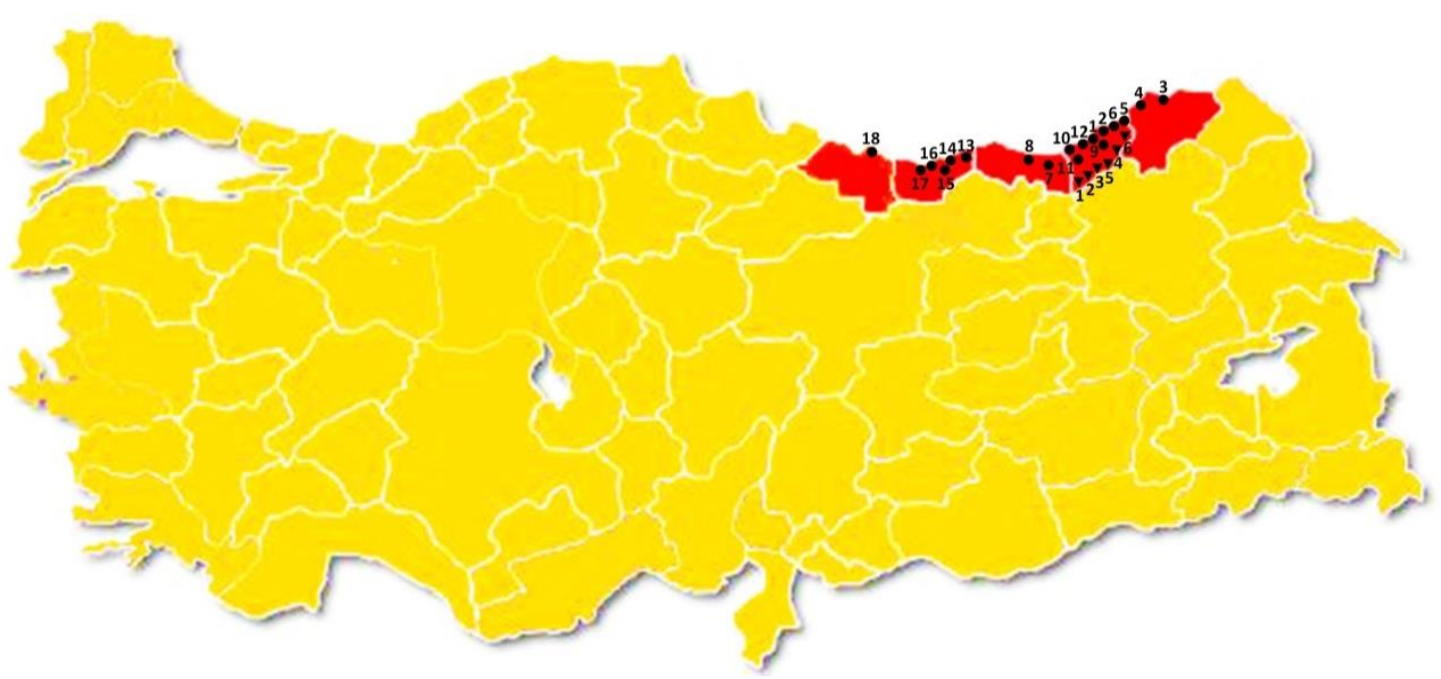

Figure 1. Distribution and locations of sampling points. $\bullet$ Eighteen randomly collected $C$. sinensis genotypes. $\mathbf{\nabla}$ Six C. sinensis varieties provided by the Rize Ataturk Tea and Horticulture Research Institute

\section{For genetic diversity study}

\section{ISSR primers}

Genomic DNAs were tested on 59 randomly selected ISSR primers. From these primers, 15 of them, which could be repeatable and polymorphic, were used in the PCR reactions (Table 2).

\section{Polymerase chain reaction (PCR) protocols}

PCR analysis was performed on a Bio-Rad T100 TM device. For PCR reaction, a total of $15 \mu$ l solution, which included $1.2 \mu \mathrm{l}$ dNTP $(2.5 \mathrm{mM}), 1.5 \mu \mathrm{l} 10 \mathrm{X}$ Taq Buffer, $1.5 \mu \mathrm{l}$ HQ Buffer, 1 pmol ISSR marker, $5 \mu$ genomic DNA, $3.8 \mu \mathrm{l}$ dH2O, $1 \mu \mathrm{l}$ (2.5 units) DNA Taq polymerase, was prepared on 96 x $0.2 \mathrm{ml}$ PCR plates. For-amplification, fragment replications were made in the form of $300 \mathrm{~s}$ at a final extension temperature of $72{ }^{\circ} \mathrm{C}$ after 40 cycles, after 1 cycle pre-denaturation at $95{ }^{\circ} \mathrm{C}$ for $180 \mathrm{~s}, 40$ cycles at $95^{\circ} \mathrm{C}$ for $45 \mathrm{~s}, 40$ cycles at marker binding temperature of $55{ }^{\circ} \mathrm{C}$ for $45 \mathrm{~s}$, and 40 cycles at $72{ }^{\circ} \mathrm{C}$ for $2 \mathrm{~min}$. PCR products were separated by running them on $2 \%$ agarose gel. Separated DNA bands were placed on a UV transilluminator and DNA bands were displayed.

\section{Determination of polymorphism rates of primers}

The polymorphism ratios of ISSR primers were calculated by following formula:

Polymorphism rate $(\%)=($ Number of polymorphic bands $/$ Tptal number of bands $) \times 100$

\section{Statistical analysis}

Of the 59 ISSR primers tested, 15 produced clear and polymorphic bands and were selected for further analysis. The bands on the agarose gel images were scored either " 1 " or " 0 " according to the presence or absence. Strong bands were evaluated in scoring and a similarity index was created. 
Dendrogram data, based on the similarity index, with the results obtained, were analyzed according to the Unweighted Pair Group Method with Arithmetic Mean (UPGMA) method (Rohlf, 1998).

Table 2. ISSR primers used in the study

\begin{tabular}{|c|c|c|c|}
\hline Primer name & Primer sequence (5'-3') & Primer name & Primer sequence (5'-3') \\
\hline UBC 808 & $(\mathrm{AG}) 8 \mathrm{C}$ & UBC 834 & $(\mathrm{AG}) 8 \mathrm{YT}$ \\
\hline UBC 809 & (GA)8T & UBC 836 & (AG)8YA \\
\hline UBC 816 & (CA)8T & UBC 841 & (GA)8YC \\
\hline UBC 825 & (AC) $8 \mathrm{~T}$ & UBC 842 & (GA)8YG \\
\hline UBC 826 & (AC) $8 \mathrm{C}$ & UBC 843 & (CT)8RA* \\
\hline UBC 827 & (AC) $8 \mathrm{G}^{*}$ & UBC 845 & (CT)8RG \\
\hline UBC 840 & (GA)8YT* & UBC 847 & $(\mathrm{CA}) 8 \mathrm{RC}$ \\
\hline UBC 841 & (GA) $8 \mathrm{YC}^{*}$ & UBC 848 & (CA)8RG \\
\hline UBC 844 & $(\mathrm{CT}) 8 \mathrm{RC}$ & UBC 851 & (GT)8YG \\
\hline UBC 850 & (GT)8YC* & UBC 852 & (CT)8RA* \\
\hline UBC 855 & $(\mathrm{AC}) 8 \mathrm{YT}^{*}$ & UBC 856 & (AC)8YA \\
\hline UBC 868 & $(\mathrm{GAA}) 6$ & UBC 857 & (AC)8YG* \\
\hline UBC 807 & (AG)8T & UBC 858 & (TG) $8 \mathrm{RT}^{*}$ \\
\hline UBC 810 & $(\mathrm{GA}) 8 \mathrm{~T}$ & UBC 859 & (TG)8RC* \\
\hline UBC 811 & $(\mathrm{GA}) 8 \mathrm{C}$ & UBC 860 & (TG)8RA* \\
\hline UBC 812 & $(\mathrm{GA}) 8 \mathrm{~A}$ & UBC 866 & (CT) $8 \mathrm{C}$ \\
\hline UBC 814 & (CT) $8 \mathrm{~A}$ & UBC 887 & $\operatorname{DVD}(\mathrm{TC}) 8$ \\
\hline UBC 815 & (CT) $8 \mathrm{G}$ & UBC 888 & $\mathrm{BDB}(\mathrm{CA}) 8$ \\
\hline UBC 818 & (CA) $8 \mathrm{G}$ & UBC 889 & $\operatorname{DBD}(\mathrm{AC}) 8$ \\
\hline UBC 819 & (GT) $8 \mathrm{~A}$ & UBC 890 & $\operatorname{VHV}(G T) 8$ \\
\hline UBC 820 & (GT) $8 \mathrm{~T}^{*}$ & UBC 891 & HVH(TG)7 \\
\hline UBC 821 & (GT) $8 \mathrm{~T}$ & ISSR 7 & $(\mathrm{AG}) 8 \mathrm{YC}^{*}$ \\
\hline UBC 822 & (TC) $8 \mathrm{~A}$ & ISSR 9 & $(\mathrm{CT}) 9 \mathrm{RC}$ \\
\hline UBC 823 & (TC) $8 \mathrm{C}$ & ISSR 16 & (TCC)5RY \\
\hline UBC 824 & (TC) $8 \mathrm{G}$ & ISSR 21 & $(\mathrm{AG}) 8 \mathrm{YT}^{*}$ \\
\hline UBC 825 & (AC) $8 \mathrm{~T}^{*}$ & ISSR 28 & $\mathrm{~A}(\mathrm{GAAA}) 4 \mathrm{G}$ \\
\hline UBC 826 & (AC) $8 \mathrm{C}$ & ISSR 43 & (GT)8YA \\
\hline UBC 828 & (TG) $8 \mathrm{~A}$ & ISSR 47 & (AG) $8 \mathrm{Y}$ \\
\hline UBC 830 & (TG) $8 \mathrm{G}$ & & \\
\hline
\end{tabular}

*Polymorphic primers

\section{Results and discussion}

\section{ISSR amplification results}

In this study, molecular characterization of 18 seedling tea genotypes and 6 standard varieties grown in the Eastern Black Sea Region was performed by 59 ISSR primers. First 59 ISSR primers were tested on 8 genotypes- then 15 ISSR primers producing reproducible and polymorphic bands, were used in the molecular characterization of all samples (Table 2). Gel images and amplification products are shown in Figure 2. Today, it is important to perform genetic diversity analysis to have information about changes that may occur about the sustainable use and future status of plant genetic resources, to evaluate the evolutionary process of a population, and conservation of 
species (Pan et al., 2017; Yun-qinq et al., 2019). Many DNA molecular marker techniques based on PCR technology have been developed in the characterization of plant gene sources. The most known DNA marker techniques and used by many researchers are ISSR, RAPD, AFLP, SRAP. The ISSR DNA molecular marker technique, which is frequently used in the fields of genetic diversity, gene tagging, phylogenetic studies, genome mapping, and evolutionary biology, is among the most preferred, especially due to its ease of application and repeatability (Kafkas et al., 2006; Norozi et al., 2009; Nazafzadeh et al., 2014). Furthermore, the fact that ISSR markers are more efficient than other markers in genetic diversity assessment and their ability to produce more polymorphic bands increases the applicability of these markers (Kumar and Agrawal, 2019). The researches revealed that varieties that cannot be separated by RAPD markers can be separated by ISSR markers (Indu et al., 2020). This finding suggests that the evolution rate of ISSRs may be faster than the RAPDs in the tea samples studied. Therefore, the ISSR marker technique is suitable for use in the study of genetic diversity and the determination of genetic relationships of closely related tea varieties. Different studies have also indicated that ISSR markers show higher levels of polymorphism compared to RAPD markers (Yang et al., 1996; Nagaoka and Ogihara, 1997; Parsons et al., 1997; Esselman et al., 1999).

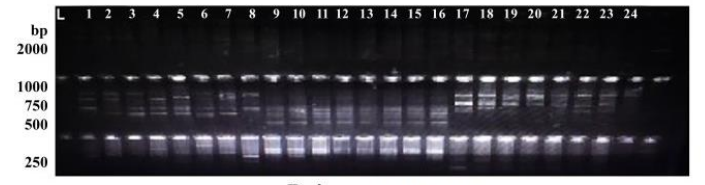

Primer UBC827

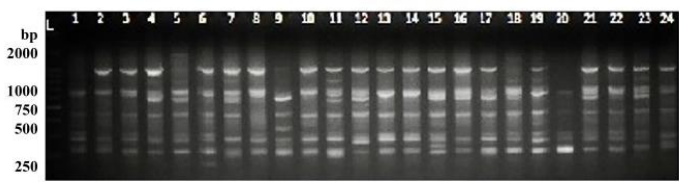

Primer ISSR-7

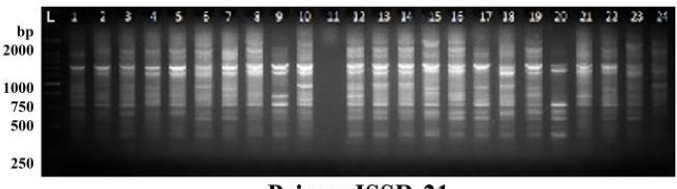

Primer ISSR-21

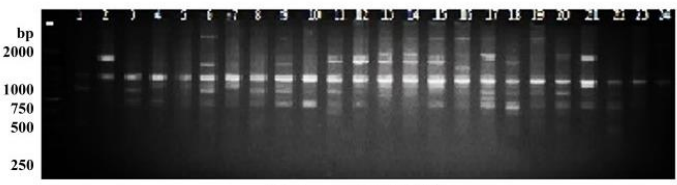

Primer UBC859

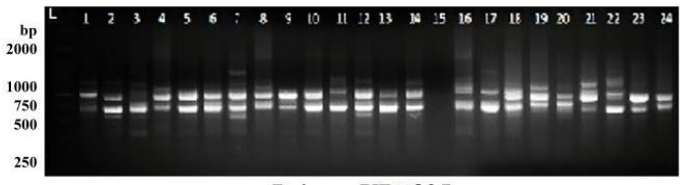

Primer UBC825

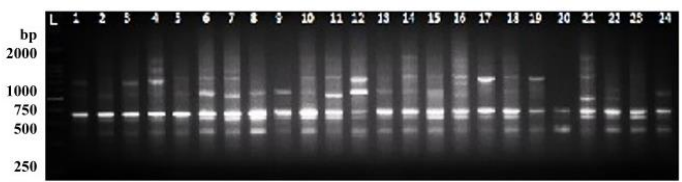

Primer UBC820

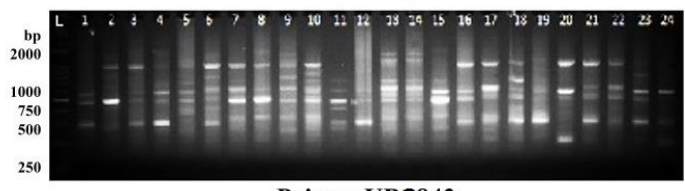

Primer UBC843

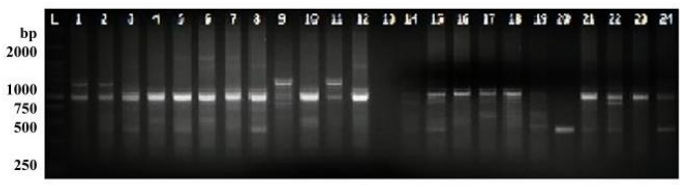

Primer UBC858

Figure 2. Image of amplification products generated with the ISSR Primers, L: $5 \mu l$ DNA (ladder)

In this study the total number of clearly visible bands was 109 , and 84 of them were polymorphic. Band sizes ranged between 150 and 1500 base pairs (bp) and the polymorphism rate (PR) was 77\%. Number of polymorphic ISSR bands ranged between 2 and 8 that minimum and maximum number of bands were given by UBC 858 , and UBC 820 and UBC 843 primers, respectively. Polymorphism rates were observed in the range of $50 \%$ to $100 \%$ among the primers that ISSR 21 showed the lowest polymorphism, while UBC 843, UBC 850, UBC 860, and UBC 852 primers showed the highest polymorphism 
(Table 3). All available primers cannot be used in all plant species, so it is necessary to develop and select appropriate primers for each plant species and variety. Christopoulos (2010) used 95 ISSR primers in walnut, and 7 of them were polymorphic; ZafarPashanezhad et al. (2020) tried 30 ISSR primers in Eruca sativa, and 19 of them were polymorphic; Atalmış (2007) detected 15 ISSR primers as polymorphic out of 17 primers in melon; Demirel (2013) found that 14 primers as polymorphic among 54 ISSR primers used in wheat; Kaç (2013) found a total of 12 primers as polymorphic of 21 ISSR primers used in tea, and Çeker (2008) tried 65 ISSR primers in chickpeas and determined that 11 of them were polymorphic. These results are similar to the results of our study. Polymorphic primers will be the resource for future studies to be conducted on tea. Karadut and Kafkas (2013) used 137 ISSR primers in pistachio, walnut, apple, apricot, and cherry varieties, and they obtained 791 bands in pistachio, 613 bands in walnuts, 696 bands in apples, 666 bands in apricots, and 514 bands in cherries. In a study conducted with 91 chickpea genotypes of Turkish origin and 2 chickpea varieties, researchers managed to produce a total of 242 bands from 11 polymorphic ISSR primers (Çeker, 2008). A total of 391 bands were obtained from 11 polymorphic ISSR primers in the genus Ankyropetalum Fenzl found in Turkey (Atgüden, 2016). Although a smaller number of bands we obtained in tea samples, 84 bands were sufficient to distinguish tea genotypes and varieties from each other. In a study using 6 different ISSR primers on the endangered rare endemic species Parrotia subaequalis, the researchers determined that there were large genetic differences among 25 separate samples in the population with a polymorphism rate of $79.66 \%$ (Yun-xia et al., 2020). In another biodiversity study, on Trichosanthes dioica, using ISSR, SCoT, and SRAP markers, the researchers reported that 20 different ISSR primers gave a $95.96 \%$ polymorphism ratio and an average number of 15.25 bands. The researchers reported that ISSR markers out of these 3 different marker types used were more informative in the assessment of genetic diversity and produced a higher average number of polymorphic bands (Kumar and Agrawal, 2019). Although the highest polymorphism rates obtained in these studies on different species were lower than the polymorphism rates found in this study, the average number of bands obtained were higher compared to our study.

\section{Similarity index and genetic relationship dendrogram}

The numbering sequence created for the genotype and varieties of tea was presented in Table 1. Clustering analysis was performed by the UPGMA method (Fig. 3). The Dendrogram showed that two branches, A and B, were formed. It was detected that the group B contains 1 genotype, and the remaining 23 genotypes constitute the group $\mathrm{A}$ which was mainly divided into two as A1 and A2. The A1 contains 2 genotypes and the A2 contains 21 genotypes, and the A2 group is also divided into subgroups. The dendrogram revealed that the most distantly related genotypes to the others were Güneysu and Pazar, while the most similar genotypes to each other were İyidere and Derepazari. A2 group forms the main group with various genotypes consisting of 6 subgroups. The first subgroup consisted of Tirebolu1-Hamzabey-Çayeli. In the second subgroup, the Tirebolu3-Hayrat1-Ardeşen genotype and their varieties are intertwined. There are 8 genotypes in the third subgroup, and this of-Hayrat2-Fener3 - FenerTirebolu4-Tirebolu5-Iyidere-Derepazari genotype and its varieties are also intertwined. İyidere-Derepazarı genotypes were found genetically identical. The genotypes of Pazar2-Hopa-Muradiye-Institute in the fourth subgroup also formed a group among themselves. The last subgroup contains 3 genotypes and has been sampled from nearby 
provinces. Pazar-Arhavi- Findiklı in this group show a close relationship among them. The similarity levels varied between 0.62 and 0.97 among the genotypes. In another study, the genetic similarity levels between 19 tea varieties taken from the Rize region were between 0.26 and 0.75 (Kaç, 2013). When the tea genotypes collected from the current tea growing regions were examined, a $62 \%$ similarity was detected among them. The ISSR molecular marker technique was used to determine the genetic relationships among 40 wild tea plants grown in Greece, and the genetic similarity rates were determined as 0.41, 0.37, and 0.55 (Liu et al., 2012). Yao et al. (2008) used the ISSR molecular marker technique to determine the genetic diversity and relationship among 48 tea varieties brought from China, Japan and Kenya, and they found that there was a greater amount of diversity among Chinese varieties than in Japan, and Kenya. The coefficient of gene differentiation (GST) was found as 0.202 , indicating a high degree of genetic diversity in these populations. In another study conducted to reveal the possible genetic variation of $C$. sinensis caused by electromagnetic fields, the researchers used 10 ISSR and 8 SCoT primers, and they reported that ISSR primer sequences showed more variation compared to SCoT sequences (Azizi et al., 2020). Looking at the tea varieties in general, it is observed that genetic expansions have emerged. It is argued that this expansion is due to cross-pollination. The frequent preference of ISSR primers in $C$. sinensis genetic diversity studies in general by researchers supports our study. The first tea seeds to come to Turkey were taken from the same region. For many years, the seeds of plants grown from these seeds have been used in the establishment of new tea orchard. In this respect, since the population has been pollinated and fertilized within itself for many years, the genotypes and varieties formed from the seeds have shown a great deal of similarity. However, those that differ genetically should be examined and investigated morphologically.

Table 3. Allele numbers and polymorphism rates of polymorphic ISSR primers used in tea genotypes and varieties

\begin{tabular}{c|c|c|c}
\hline Primer name & Total number of bands & $\begin{array}{c}\text { Number of } \\
\text { polymorphic bands }\end{array}$ & $\begin{array}{c}\text { Percentage polymorphism } \\
\text { (\%) }\end{array}$ \\
\hline UBC 820 & 10 & 8 & 80.0 \\
UBC 825 & 8 & 6 & 75.0 \\
UBC 827 & 6 & 4 & 66.6 \\
UBC 840 & 6 & 4 & 66.6 \\
UBC 841 & 8 & 6 & 75.0 \\
UBC 843 & 8 & 8 & 100.0 \\
UBC 850 & 7 & 7 & 100.0 \\
UBC 852 & 7 & 7 & 100.0 \\
UBC 855 & 6 & 5 & 83.3 \\
UBC 858 & 3 & 2 & 66.6 \\
UBC 857 & 6 & 5 & 83.3 \\
UBC 859 & 5 & 4 & 80.0 \\
UBC 860 & 6 & 6 & 100.0 \\
ISSR 7 & 11 & 6 & 54.5 \\
ISSR 21 & 12 & 6 & 50.0 \\
Total & 109 & 84 & - \\
Mean & 7.3 & 5.6 & 77 \\
\hline
\end{tabular}




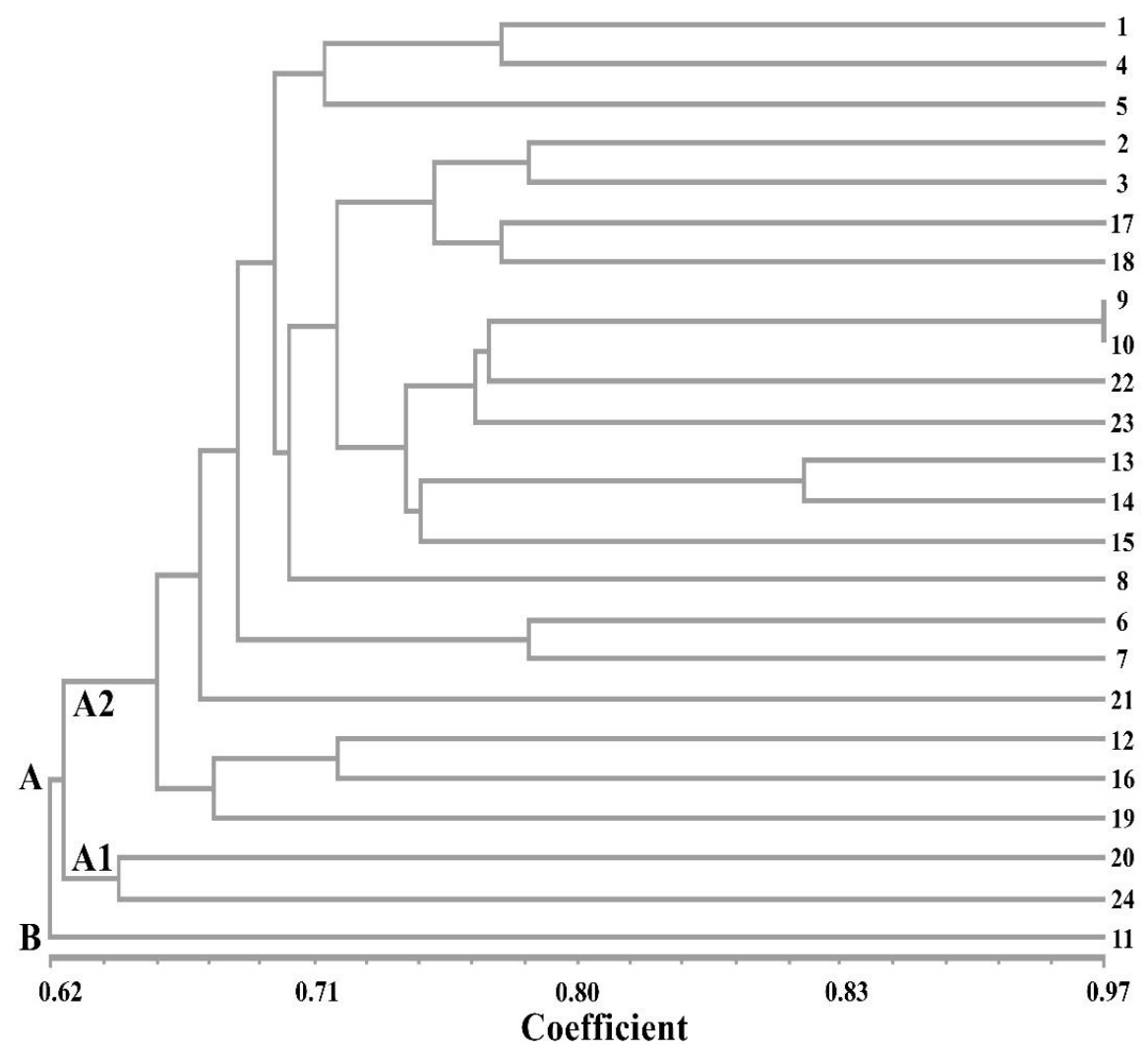

Figure 3. Dendrogram based on the similarity index between C. sinensis genotypes and varieties using ISSR markers

\section{Conclusions}

The study was conducted with 18 different genotypes and 6 different varieties of standard tea. Genotypes were selected as a representation from tea orchard of Artvin, Rize, Trabzon, Giresun, and Ordu provinces where tea is grown in Turkey. In the study, a total of 59 different ISSR primers were used and 15 of them were determined to be polymorphic for tea. It has been found that generally tea genotypes propagated by seed are genetically similar at a rate of $62 \%$. For example, the genetic structures of the IyidereDerepazarı genotypes were found to be similar to each other (Fig. 3). A total of $38 \%$ of the tea population was determined to show a difference, which was found to occur due to genetic expansion. In the market, the idea that the tea of different companies or regions is of better quality is not entirely due to genotype, but also that the ecology in which the tea grows is effective in climate and soil characteristics, as well as processing technology. At the same time, this genetic difference can be used in breeding study.

\section{REFERENCES}

[1] Abdel-Mawgood, A. L. (2012): DNA Based Techniques for Studying Genetic Diversity. - In: Caliskan, M. (ed.) Genetic Diversity in Microorganisms. InTech, Rijeka, pp 95-122.

[2] Altindal, D. (2019): Determination of genetic diversity of natural sage populations in Muğla region of Turkey. - International Journal of Environmental Science and Technology 16(9): 5219-5226. 
[3] Anonymous (2016): World Atlas, The world's top ten tea producing nations. Economics. https://www.worldatlas.com/articles/the-worlds-top-10-tea-producing-nations.html Accessed 23 May 2021

[4] Anonymous (2018): Tea Agricultural Products Markets. - Agricultural Economy and Policy Development Institute, Item No: 04, Rize.

[5] Atalmış, F. (2007): Identification of melon varieties grown in the Aegean Region using morphological and ISSR DNA markers. - Master Thesis, Ege University, Institute of Science, Department of Horticulture, İzmir.

[6] Atgüden, C. (2016): Determination of kinship relations between Ankyropetalum Fenzl (Caryophyllaceae) taxa spread naturally in Turkey by ISSR method. - Master Thesis, Harran University, Graduate School of Natural and Applied Sciences, Department of Biology, Şanlıurfa.

[7] Azizi, S. M. Y., Sarghein, S. H., Majd, A., Peyvandi, M. (2020): The assessment of electromagnetic fields-caused genetic diversity of Tea Camellia sinensis L. using ISSR and SCoT markers. - Brazilian Journal of Botany 43(4): 907-920.

[8] Bandyopadhyay, T. (2011): Molecular marker technology in genetic improvement of tea. - International Journal of Plant Breeding and Genetics 5(1): 23-33.

[9] Benzie, I. F., Szeto, Y. T. (1999): Total antioxidant capacity of teas by the ferric reducing/antioxidant power assay. - Journal of agricultural and food chemistry 47(2): 633-636.

[10] Briggs, F., Knowles, P. F. (1967): Introduction to Plant Breeding. - Reinhold Publishing Corporation, London.

[11] Çeker, A. (2008): Molecular characterization of chickpea genotypes collected from some region of Turkey. - Master Thesis, Çukurova University, Institute of Science, Department of Biotechnology, Adana.

[12] Christopoulos, M. V., Rouskas, D., Tsantili, E., Bebeli, P. J. (2010): Germplasm diversity and genetic relationships among walnut (Juglans regia L.) cultivars and Greek local selections revealed by Inter-Simple Sequence Repeat (ISSR) markers. - Scientia Horticulturae 125(4): 584-592.

[13] De Costa, W., Mohotti, A. J., Wijeratne, M. A. (2007): Ecophysiology of tea. - Brazilian Journal of Plant Physiology 19(4): 299-332.

[14] Demirel, F. (2013): Molecular and morphological identification of diploid ( $T$. monococcum) and tetraploid (T. dicoccum) spelled wheat village varieties collected from Kastamonu. - Master Thesis, Erciyes University, Institute of Science, Department of Field Crops, Kayseri.

[15] Ercisli, S. (2004): A short review of the fruit germplasm resources of Turkey. - Genetic Resources and Crop Evolution 51(4): 419-435.

[16] Esselman, E. J., Jianqiang, L., Crawford, D. J., Windus, J. L., Wolfe, A. D. (1999): Clonal diversity in the rare Calamagrostis porter ssp. insperata (Poaceae): Comparative results for allozymes and random amplified polymorphic DNA (RAPD) and intersimple sequence repeat (ISSR) markers. - Molecular Ecology 8: 443-451.

[17] Ferruzzi, M. G. (2010): The influence of beverage composition on delivery of phenolic compounds from coffee and tea. - Physiology \& Behavior 100(1): 33-41.

[18] Harlan, J. R. (1995): The Living Fields: Our Agricultural Heritage. - Cambridge University Press, Cambridge.

[19] Indu, R., Kaushik, R. A., Deepak, R., Maloo, S. R., Manish, C. (2020): Molecular characterization of chrysanthemum by using RAPD and ISSR markers. - Journal of Pharmacognosy and Phytochemistry 9(1): 1423-1429.

[20] Ji, P. Z., Li, H., Gao, L. Z., Zhang, J., Cheng, Z. Q., Huang, X. Q. (2011): ISSR diversity and genetic differentiation of ancient tea (Camellia sinensis var. assamica) plantations from China: implications for precious tea germplasm conservation. - Pakistan Journal of Botany 43(1): 281-291. 
[21] Kaç, M. (2013): Identification of tea varieties with ISSR markers. - Master Thesis, Recep Tayyip Erdogan University, Graduate School of Natural and Applied Sciences, Department of Biology, Rize.

[22] Kafkas, S., Ozkan, H., Ak, B. E., Acar, I., Atl1, H. S., Koyuncu, S. (2006): Detecting DNA polymorphism and genetic diversity in a wide pistachio germplasm: comparison of AFLP, ISSR, and RAPD markers. - Journal of the American Society for Horticultural Science 131(4): 522-529.

[23] Kafkas, S., Ercisli, S., Doğan, Y., Ertürk, Y., Haznedar, H., Sekban, R. (2009): Polymorphism and genetic relationships among tea genotypes from Turkey revealed by amplified fragment length polymorphism markers. - Journal of the American Society for Horticultural Science 134(4): 428-434. https://doi.org/10.21273/JASHS.134.4.428.

[24] Karadut, Ö., Kafkas, S. (2013): Development of new ISSR primers from pistachio SSR loci. - Çukurova University Journal of Science and Engineering Sciences 29(2): 139-148.

[25] Kaya, Z., Raynal, D. J. (2001): Biodiversity and conservation of Turkish forests. Biological Conservation 97(2): 131-141.

[26] Kumar, J., Agrawal, V. (2019): Assessment of genetic diversity, population structure and sex identification in dioecious crop, Trichosanthes dioica employing ISSR, SCoT and SRAP markers. - Heliyon 5(3): e01346.

[27] Lai, J. A., Yang, W. C., Hsiao, J. Y. (2001): An assessment of genetic relationships in cultivated tea clones and native wild tea in Taiwan using RAPD and ISSR markers. Botanical Bulletin-Academia Sinica 42: 93-100.

[28] Liu, B., Sun, X., Wang, Y., Li, Y., Cheng, H., Xiong, C., Wang, P. (2012): Genetic diversity and molecular discrimination of wild tea plants from Yunnan province based on inter-simple sequence repeats (ISSR) markers. - African Journal of Biotechnology 11(53): 11566-11574.

[29] Nagaoka, T., Ogihara, Y. (1997): Applicability of inter-simple sequence repeat polymorphisms in wheat for use as DNA markers in comparison to RFLP and RAPD markers. - Theoretical and Applied Genetics 94(5): 597-602.

[30] Najafzadeh, R., Arzani, K., Bouzari, N., Saei, A. (2014): Genetic diversity assessment and identification of new sour cherry genotypes using intersimple sequence repeat markers. - International Journal of Biodiversity Article ID 308398: 1-8. http://dx.doi.org/10.1155/2014/308398.

[31] Noroozi, A., Mokhtar, J. J., Baghizadeh, M. (2009): The genetic diversity of Iranian pistachio (Pistacia vera L.) cultivars revealed by ISSR markers. - Biological Diversity and Conservation 2(2): 50-56.

[32] Nybom, H., Weising, K., Rotter, B. (2014): DNA fingerprinting in botany: past, present, future. - Investigative Genetics 5(1): 1.

[33] Pan, L., Fu, J., Zhang, R., Qin, Y., Lu, F., Jia, L., Hu, Q., Liu, C., Huang, L., Liang, G. (2017): Genetic diversity among germplasms of Pitaya based on SSR markers. - Scientia Horticulturae 225: 171-176.

[34] Panda, H. (2011): The Complete Book on Cultivation and Manufacture of Tea. - Asia Pacific Business Press, New Delhi.

[35] Parsons, B. J., Newbury, H. J., Jackson, M. T., Ford-Lloyd, B. V. (1997): Contrasting genetic diversity relationships are revealed in rice (Oryza sativa L.) Using different marker types. - Molecular Breeding 3: 115-125.

[36] Rahimi, M., Nazari, L., Kordrostami, M., Safari, P. (2018): SCoT marker diversity among Iranian Plantago ecotypes and their possible association with agronomic traits. Scientia Horticulturae 233: 302-309.

[37] Rahimi, M., Kordrostami, M., SafaeiChaeikar, S. (2019): Genetic variation, population structure and the possibility of association mapping of biochemical and agronomic traits using dominant molecular markers in Iranian tea accessions. - Iranian Journal of Science and Technology, Transactions A: Science 43(6): 2769-2780. 
[38] Rajpal, V. R., Rao, S. R., Raina, S. (2016): Molecular Breeding for Sustainable Crop Improvement. Vol 2. - Springer, Berlin.

[39] Rohlf, F. J. 1998. NTSYS: pc, Numerical Taxonomy and Multivariate Analysis System, Version 2.01. - Setauket, New York.

[40] Roy, S. C., Chakraborty, B. N. (2009): Genetic diversity and relationships among tea (Camellia sinensis) cultivars as revealed by RAPD and ISSR based fingerprinting. Indian Journal of Biotechnology 8: 370-376.

[41] Saghai-Maroof, M. A., Soliman, K. M., Jorgensen, R. A., Allard, R. W. (1984): Ribosomal DNA spacer-length polymorphism in barley: mendelian inheritance, chromosomal location, and population Dynamics. - Proceedings of the National Academy of Sciences 81: 8014-8019. https://doi.org/10.1073/pnas.81.24.8014.

[42] Upadhyaya, H., Gowda, C., Sastry, D. (2008): Management of Germplasm Collections and Enhancing Their Use by Mini Core and Molecular Approaches. - In: Capacity Building for Development and Implementation of Risk Management Systems on Genetic Resources: Proceedings of the APEC-ATCWG Workshop, Taichung, Chinese Taipei, pp. 35-70.

[43] Yang, W., Oliveira, A. C., Godwin, I., Scheritz, K., Bennetzen, J. L. (1996): Comparison of DNA marker technologies in characterizing plant genome diversity: variability in Chinese Sorghums. - International Journal of Crop Science and Technology 36: 16691676.

[44] Yao, M. Z., Chen, L., Liang, Y. R. (2008): Genetic diversity among tea cultivars from China, Japan and Kenya revealed by ISSR markers and its implication for parental selection in tea breeding programmes. - Plant Breeding 127: 166-172.

[45] Yun-qing, H., Xiao-bo, L., Xiao-ling, W. (2019): Genetic diversity of the endangered Acer pentaphyllum diels by ISSR analysis. - Journal of Sichuan University (Natural Science Edition) 01: 161-166.

[46] Yun-xia, C., Jun-fan, J., Cheng-hui, N., Xiao-ming, X. (2020): ISSR Analysis on genetic diversity of endangered plant Parrotia subaequalis in dalonggou of Yixing, Jiangsu. - E3S Web of Conferences 145(1): 01026.

[47] Zafar-Pashanezhad, M., Shahbazi, E., Golkar, P., Shiran, B. (2020): Genetic variation of Eruca sativa L. genotypes revealed by agro-morphological traits and ISSR molecular markers. - Industrial Crops and Products 145: 111992.

[48] Zhang, Y., Zhang, X., Chen, X., Sun, W., Li, J. (2018): Genetic diversity and structure of tea plant in Qinba area in China by three types of molecular markers. - Hereditas 155(1): 22 . 